\title{
Mixotrophic feeding of Fragilidium subglobosum (Dinophyceae) on three species of Ceratium: effects of prey concentration, prey species and light intensity
}

\author{
Per Juel Hansen ${ }^{1, *}$, Torkel Gissel Nielsen ${ }^{2}$ \\ ${ }^{1}$ Marine Biological Laboratory, Strandpromenaden 5, DK-3000 Helsinger, Denmark \\ ${ }_{2}^{2}$ National Environmental Research Institute, Department of Marine Ecology and Microbiology, Frederiksborgvej 399 , \\ PO Box 358, DK-4000 Roskilde, Denmark
}

\begin{abstract}
Growth and grazing responses of the mixotrophic dinoflagellate Fragilidium subglobosum were studied as a function of prey concentration, prey species, and light intensity in laboratory cultures. In monospecific (exclusively phototrophic) cultures the growth rate of $F$. subglobosum was $0.16 \mathrm{~d}^{-1}$ (doubling time $4.3 \mathrm{~d}$ ) at a light intensity of $45 \mu \mathrm{mol}$ photons $\mathrm{m}^{-2} \mathrm{~s}^{-1}$ In cultures supplied with the phototrophic dinoflagellate Ceratium tripos at a similar light intensity, the growth rate of $F$. subglobosum reached a maximum level of $0.5 \mathrm{~d}^{-1}$ (doubling time $1.4 \mathrm{~d}$ ) at a prey concentration of ca $10 \mathrm{C}$. tripos cells $\mathrm{ml}^{-1}$. The functional response of $F$. subglobosum followed a Holling type I functional response. At prey concentrations which resulted in maximum growth rate, growth yield equalled ca $40 \%$. However, at prey concentrations which led to lower growth rates, growth yield exceeded $100 \%$, indicating that food uptake by $F$ subglobosum stimulated photosynthesis at low prey concentrations. When $C$. tripos cells were added in excess, growth and ingestion rate of $F$. subglobosum increased with light intensity within the studied range ( 9 to $45 \mu \mathrm{mol}$ photons $\mathrm{m}^{-2} \mathrm{~s}^{-1}$ ). Growth rates of $F$. subglobosum were higher with $C$. tripos as food than with C. furca and C. fusus.
\end{abstract}

KEY WORDS: Mixotrophy · Growth - Grazing · Holling type I functional response - Prey selection Dinoflagellate Fragilidium subglobosum · Ceratium spp. Light

\section{INTRODUCTION}

Phototrophic dinoflagellates are an important group of phytoplankton, occasionally forming red tides in coastal seas. Ingestion of prey by photosynthetic (plastidic) dinoflagellates has been known for a long time, but until recently only found in a few species (Gaines \& Elbrächter 1987, Schnepf \& Elbrächter 1992). Recently, however, a large number of species collected from field samples have been found to contain food vacuoles, suggesting that mixotrophy is widespread in phototrophic forms (Bockstahler \& Coats 1993a, b, Jacobson \& Anderson 1996, Li et al. 1996). The term

•E-mail: mblpjh@inet.uni-c.dk mixotrophy is here used for organisms which combine phototrophy and phagotrophy.

Three different feeding mechanisms have been described among dinoflagellates, all allowing the ingestion of relatively large prey (Jacobson \& Anderson 1986, Gaines \& Elbrächter 1987). The efficiency of prey capture depends on size, and experimental data suggest that dinoflagellates ingest prey corresponding to their own size most efficiently (Hansen 1992). Thus dinoflagellates are true raptorial feeders. A few studies have indicated that even large heterotrophic and mixotrophic dinoflagellates are able to feed substantially on bacteria-sized prey (Lessard \& Swift 1985, Nygaard \& Tobisen 1993, Neuer \& Cowles 1995). However, these studies have all used methods (radioactively or fluorescently labelled bacteria) which po- 
tentially may have led to artefacts or misinterpretations (see Hansen in press for review).

The role of phagotrophy in mixotrophic flagellates varies considerably. Some species are primarily heterotrophic (e.g. Poterioochromonas malhamensis, Ochromonas spp.; Fenchel 1982, Anderson et al. 1989. Sanders et al. 1990). Others have an obligate requirement for light (e.g. Dinobryon cylindricum, D. divergens, Ochromonas sp., Chrysochromulina brevifilum), and growth is primarily due to photosynthesis (Caron et al. 1989, Veen 1991, Keller 1994). Acquisition of essential growth factors is yet another role for ingestion of prey in mixotrophic flagellates (e.g. Uroglena americana; Kimura \& Ishida 1986, 1989). However our knowledge mainly derives from studies of chrysophytes and prymnesiophytes (Fenchel 1982, Anderson et al. 1989, Sanders et al. 1990, Jones et al. 1993). The role of phagotrophy in mixotrophic dinoflagellates has only been investigated in a single dinoflagellate, Gymnodinium sanguineum (Bockstahler \& Coats 1993a). This dinoflagellate feeds selectively on small oligotrich ciliates. In field samples, the daily consumption of ciliate blomass by $G$. sanguneum was tound to average $2.5 \%$ of body carbon and $4.0 \%$ of body nitrogen with maximal values of 11.6 and $18.5 \%$, respectively. This suggests that $G$. sanguineum is primarily phototrophic. Nevertheless, when $G$, sanguineum occurs in high concentrations, its predation on ciliates may be substantial.

The present paper is the third in a series of papers dealing with the mixotrophic dinoflagellate Fragilidium (= Helgolandinium) subglobosum. In the first paper, Skovgaard (1996a) describes the feeding mechanism of F subglobosum. Like Stosch (1969), Skovgaard was able to culture it photoautotrophically in monospecific cultures. In mixotrophic cultures, F. subglobosum feeds selectively on Ceratium species by direct engulfment, which is an unusual feeding mechanism for thecate dinoflagellates, but common in naked forms (Gaines \& Elbrächter 1987, Schnepf \& Elbrächter 1992). During the feeding process, the theca of Ceratium spp. is dissolved and the prey cell is transformed into a roundish food vacuole located in the center of $F$ subglobosum. When feeding on the small $C$. lineatum, F. subglobosum ingests up to 13 cells prior to encystment and subsequent cell division. However, when feeding on the large $C$. tripos, it only ingests a single cell before it divides. In both photoautotrophic and mixotrophic cultures, F. subglobosum forms division cysts as part of its life cycle.

In the second paper, Skovgaard (1996b) studied growth and ingestion responses of Fragilidium subglobosum as a function of light intensity in monospecific cultures and in cultures fed Ceratium lineatum in excess. In monospecific cultures, the maximum growth rate was obtained at a light intensity of ca $130 \mu \mathrm{mol}$ photons $\mathrm{m}^{-2} \mathrm{~s}^{-1}$. In mixotrophic cultures, the growth rate of $F$. subglobosum did not vary with light intensity within a wide range of light intensities, even though ingestion rates varied by a factor of 2 to 3. Maximum ingestion rates were obtained at intermediate light levels. At light levels below and above this level, lower ingestion rates were found.

The aim of the present paper is to study the functional and numerical response of Fragilidium subglobosum when fed Ceratium tripos. We also studied the growth and grazing response of $F$. subglobosum fed 3 Ceratium spp. separately at 3 light intensity levels.

\section{MATERIALS AND METHODS}

Culturing of organisms. The dinoflagellates Ceratium furca, C. fusus, and C. tripos were isolated from net (mesh size $20 \mu \mathrm{m}$ ) samples collected in the Kattegat (Denmark) in autumn 1992. The mixotrophic dinoflagellate Fragilidium subglobosum was isolated from the Kattegat (Skovgaard 1996a) and was provided by the culture collection of the Marine Biological Laboratory, Helsinger, Denmark. All organisms were grown as non-axenic cultures in B-medium (Hansen 1989) based on seawater $(28 \%)$ at $15 \pm 1^{\circ} \mathrm{C}$ following a light:dark cycle of 14:10 h. Illumination was provided by cool white fluorescent lamps and the organisms were kept at a light intensity of ca $20 \mu \mathrm{mol}$ photons $\mathrm{m}^{-2} \mathrm{~s}^{-1}$. Light intensity was measured using a LI-COR LI-1000 radiation sensor equipped with a flat LI-COR underwater probe. The dimensions of $F$, subglobosum were determined by microscopic measurements of Lugol's fixed cells ( $n=20$ to 30 ), and volume was calculated assuming a sphere. Cell volumes of Ceratium species were estimated from the width of the sulcus using the equations of Thomsen (1992).

Experimental conditions. All experiments were carried out in 250 or $750 \mathrm{ml}$ polystyrene bottles allowing light to penetrate from only 1 direction. The experimental bottles were mounted vertically on a rotating wheel $(1 \mathrm{rpm})$ in order to keep the algae in suspension.

Numerical and functional responses of Fragilidium subglobosum. Experiments were carried out to study growth and grazing rates of $F$. subglobosum fed Ceratium tripos at prey concentrations ranging from 0 to 60 cells $\mathrm{ml}^{-1}$ at an illumination of $45 \mu \mathrm{mol}$ photons $\mathrm{m}^{-2}$ $\mathrm{s}^{-1}$. For each prey concentration, 3 bottles with $F$. subglobosum and 1 control bottle without F. subglobosum were incubated. The experiments were initiated by mixing cultures of $C$. tripos and $F$ subglobosum at a cell concentration ratio of $10: 1$, except at low prey concentrations $\left(<10 \mathrm{C}\right.$. tripos $\left.\mathrm{ml}^{-1}\right)$, where a lower 
concentration ratio of 5:1 was used. F. subglobosum was allowed to adapt to mixotrophic conditions for $3 \mathrm{~d}$ prior to subsampling once a day for up to $5 \mathrm{~d}$. Subsamples were ca $10 \%$ of the experimental volume. Fresh B-medium was added to the experimental bottles, and the subsamples were fixed in 1\% Lugol's (final concentration). Instantaneous growth rates of $F$. subglobosum were determined in steps of $24 \mathrm{~h}$ due to the daily dilution of the samples as: $\mu=\left[\ln \left(y_{11} / y_{10}\right)\right] t^{-1}$, where $y_{10}=$ concentration of cells at Day $t_{0}$ (cells $\mathrm{ml}^{-1}$ ), and $y_{t 1}=$ concentration of cells at Day $t_{1}$ (cells $\mathrm{ml}^{-1}$ ), and $t=$ the duration of each experiment (d). Ingestion rates of $F$. subglobosum were determined from the reduction in prey concentration over $24 \mathrm{~h}$ periods, using the control cultures to estimate prey growth rate. Ingestion rates, $U$, can be estimated using the following 2 equations:

$$
\begin{gathered}
\mathrm{d} x / \mathrm{d} t=\mu_{x} x-U y \\
\mathrm{~d} y / \mathrm{d} t=\mu_{y} y
\end{gathered}
$$

where prey $(x)$ is ingested by predator $(y)$. It is assumed that the predator $(y)$ grows exponentially with the rate constant of $\mu_{y}$, and that the prey $(x)$ grows with the rate constant of $\mu_{x}$. The mortality due to predation is $U_{y}$, where $U$ (dimension $x / y / t$ ) is the per capita ingestion rate, which is independent of $x$. As the solution to solve for $\mu$ is intractable, the ingestion rate $(U)$ was iteratively calculated with time on a computer, allowing steps of $1 \mathrm{~h}$ (the programme is available upon request from P.J.H.). Clearance was calculated as: $C=U(x) / x$. In order to study the fate of the ingested biomass, estimates of growth yield $(Y)$ were calculated as: $\{[\mu(\mathrm{m})-$ $\left.\mu(\mathrm{p})] \cdot V_{y}\right\} /\left(U \cdot V_{x}\right)$, where $U$ is the ingestion rate (cells $\left.\mathrm{d}^{-1}\right), \mu(\mathrm{m})=$ growth rate of $F$. subglobosum in mixed cultures $\left(\mathrm{d}^{-1}\right), \mu(\mathrm{p})=$ growth rate of $F$. subglobosum in purely phototrophic cultures $\left(\mathrm{d}^{-1}\right)$, and $V_{x}$ and $V_{y}$ refer to the cell volumes of $C$. tripos and $F$. subglobosum $\left(\mu \mathrm{m}^{3}\right)$, respectively.

Effects of light and prey selectivity on growth and ingestion rates. Experiments were carried out to study the effects of light and prey species on the growth and grazing response of Fragilidium subglobosum. Incubation bottles were shaded to reach light intensities of 9 , 22.5 and $45 \mu \mathrm{mol}$ photons $\mathrm{m}^{-2} \mathrm{~s}^{-1}$. F subglobosum was grown without prey prior to the experiment. Ceratium furca, C. fusus and C. tripos were used as prey at an initial biomass (cell concentration $\times$ cell volume) of $3.3 \mathrm{ppm}$ (volume fraction); this corresponds to ca $30 \mathrm{C}$. tripos, which is well above saturating levels (see 'Results'). The prey:predator biomass relationship was 10:1. The duration of the experiments was $2 \mathrm{wk}$; otherwise the conditions were as stated above. In order to test the statistical significance of differences among treatments of ingestion and growth rates, a 1 -way and 2-way ANOVA analysis, respectively, was carried out using a computer program (Sigmastat ${ }^{R}$, Jandel).

Initial prey uptake. This experiment was set up to test whether the initial prey uptake by Fragilidium subglobosum was determined by the physiology of $F$. subglobosum or, alternatively, was due to the food quality of the prey grown at different light intensities. Monospecific cultures of $F$. subglobosum were adapted to different light intensities. One set of $F$. subglobosum cultures was high-light adapted $\left(45 \mu \mathrm{mol}\right.$ photons $\mathrm{m}^{-2}$ $\left.\mathrm{s}^{-1}\right)$, while another set was low-light adapted (9 $\mu \mathrm{mol}$ photons $\mathrm{m}^{-2} \mathrm{~s}^{-1}$ ). Ceratium tripos cultures which had been adapted to high light or low light intensity were fed to each set of the adapted $F$. subglobosum cells. Mixed cultures were subsampled after $4,8,12,16,20$, 24,30 and $47 \mathrm{~h}$ and fixed with glutaraldehyde $12 \%$ final concentration). The percentage of $F$. subglobosum containing a food vacuole was determined from more than 50 cells. Three replicates were set up for each combination.

\section{RESULTS}

\section{Bioenergetics}

The ingestion rate of Fragilidium subglobosum increased as a function of prey concentration and reached a maximum level of ca 0.6 Ceratium tripos $\mathrm{d}^{-1}$ (Fig. 1A). Maximum clearance was about $0.055 \mathrm{ml} \mathrm{h}^{-1}$ or $3.4 \times 10^{4}$ body volumes $h^{-1}$ (Fig. $1 \mathrm{~B}$ ). In purely phototrophic cultures, the growth rate of $F$. subglobosum was $0.16 \mathrm{~d}^{-1}$ at a light intensity of $45 \mu \mathrm{mol} \mathrm{m} \mathrm{m}^{-2} \mathrm{~s}^{-1}$ (Fig. 2). In food-supplied cultures at a similar light intensity, the growth rate of F. subglobosum increased as a function of prey concentration and reached a maximum level of ca $0.5 \mathrm{~d}^{-1}$, at a prey concentration of about $10 \mathrm{C}$. tripos cells $\mathrm{ml}^{-1}$ (Fig 2). The cell volume of $F$. subglobosum increased from ca $45000 \mathrm{\mu m}^{3}$ in monospecific cultures to about $90000 \mu^{3}$ in food satiated cultures (Fig. 3). At prey concentrations which resulted in maximum growth rate, growth yield equalled ca $40 \%$. However, at prey concentrations which led to lower growth rates, growth yield increased to above $100 \%$ (Fig. 4).

\section{Prey selection and light intensity}

In monospecific cultures, the growth rate of Fragilidium subglobosum increased from about 0.04 to $0.11 \mathrm{~d}^{-1}$ as the light intensity increased from 9 to $45 \mu \mathrm{mol}$ photons $\mathrm{m}^{-2} \mathrm{~s}^{-1}$ (Figs. $5 \& 7$ ). In food-supplied cultures, the increase in the growth rate of $F$. subglobosum was dependent on the prey species (Figs. 6 

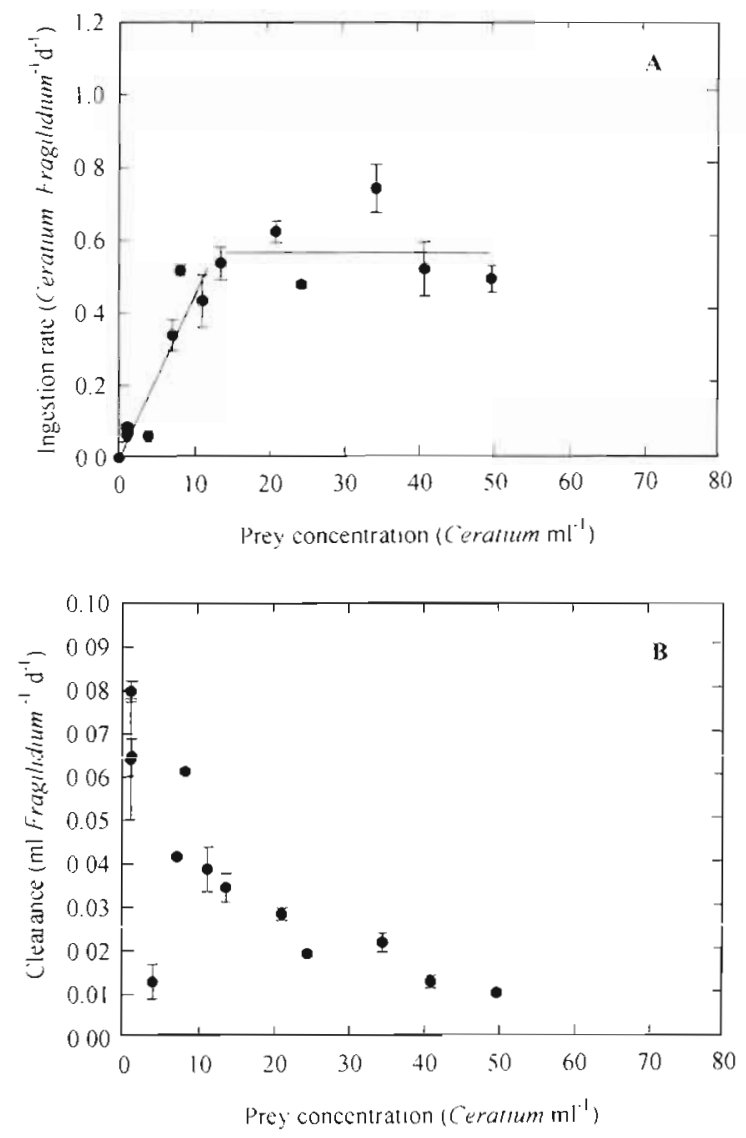

Fig. 1. Fragilidium subglobosum. (A) Ingestion rate as a function of cell concentration of Ceratium tripos. Data points represent treatment means $\pm 1 \mathrm{SE}(\mathrm{n}=3)$. Curves represent the rectilinear fit of data: $U=0.0135+0.0413 x$ for $x<$ 13.6 cells $\mathrm{ml}^{-1}, \mathrm{R}^{2}=0.94 ; U=0.5881-0.000906 x$ for $x>$ 13.6 cells $\mathrm{ml}^{-1}$. (B) Clearance as a function of cell concentration of $C$. tripos. Data points represent treatment means $\pm 1 \mathrm{SE}$

$$
(n=3)
$$

\& 7 ). The growth rate of $F$. subglobosum, when fed Ceratium tripos, increased from about $0.18 \mathrm{~d}^{-1}$ at the lowest light intensity to $0.4 \mathrm{~d}^{-1}$ at the highest light intensity. The increase in growth rate of $F$. subglobosum was significantly lower when fed the 2 smaller species (C. furca and C. fusus; $p<0.01$ ). In fact, the growth rate of $F$. subglobosum, when fed the smallest species $C$. fusus, was only slightly different from growth rates obtained in monospecific cultures of $F$. subglobosum $(p<0.05)$. The change in growth rate of $F$. subglobosum as a function of light intensity was significantly larger in cultures fed $C$. tripos and $C$. furca compared to monospecific cultures $(p<0.01)$, indicating a positive interaction between photosynthesis and phagotrophy. When F. subglobosum was fed $C$. tripos, ingestion rates increased with light intensity, suggesting that light stimulates phagotrophy in F. subglobosum (Fig. 8).

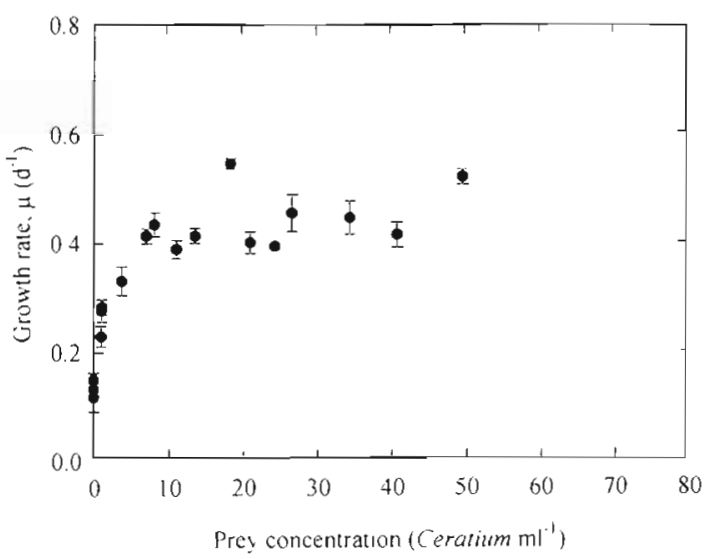

Fig. 2. Fragilidium subglobosum. Growth rate as a function of cell concentration of Ceratium tripos. Data points represent treatment means \pm 1 SE $(n=3)$

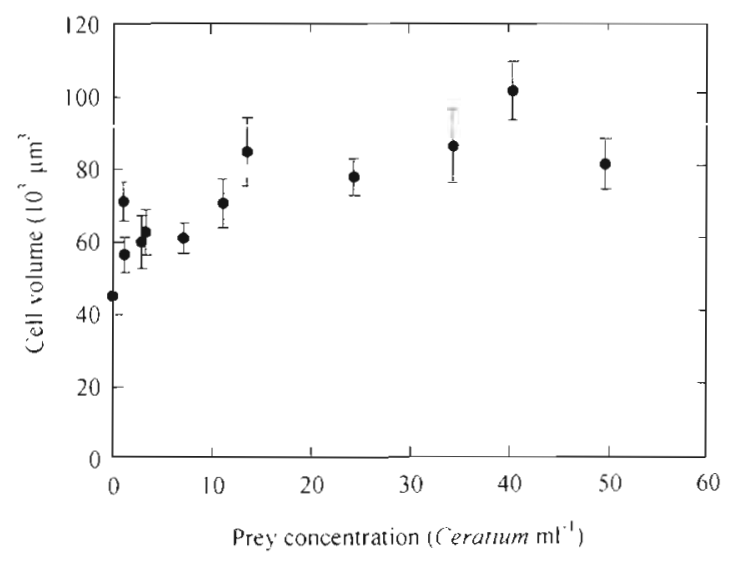

Fig. 3. Fragilidium subglobosum. Cell volume as a function of cell concentration of Ceratium tripos. Data points represent treatment means $\pm 1 \mathrm{SE}(\mathrm{n}=3)$

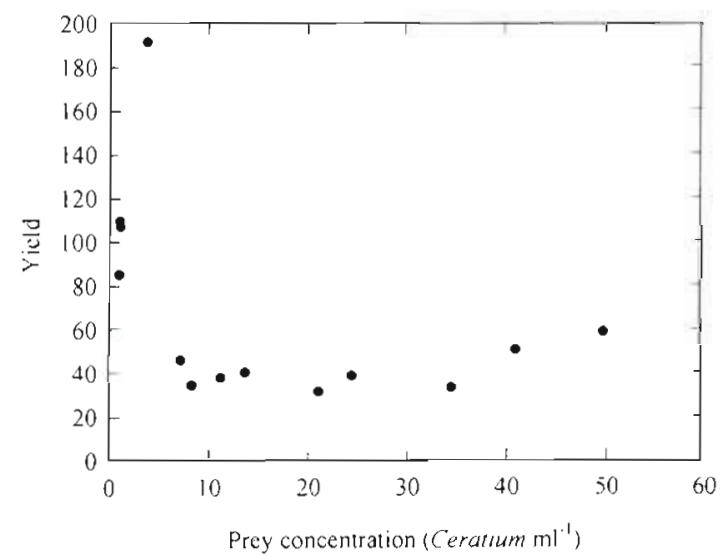

Fig. 4. Fragilidium subglobosum. Growth yield as a function of cell concentration of Ceratium tripos 

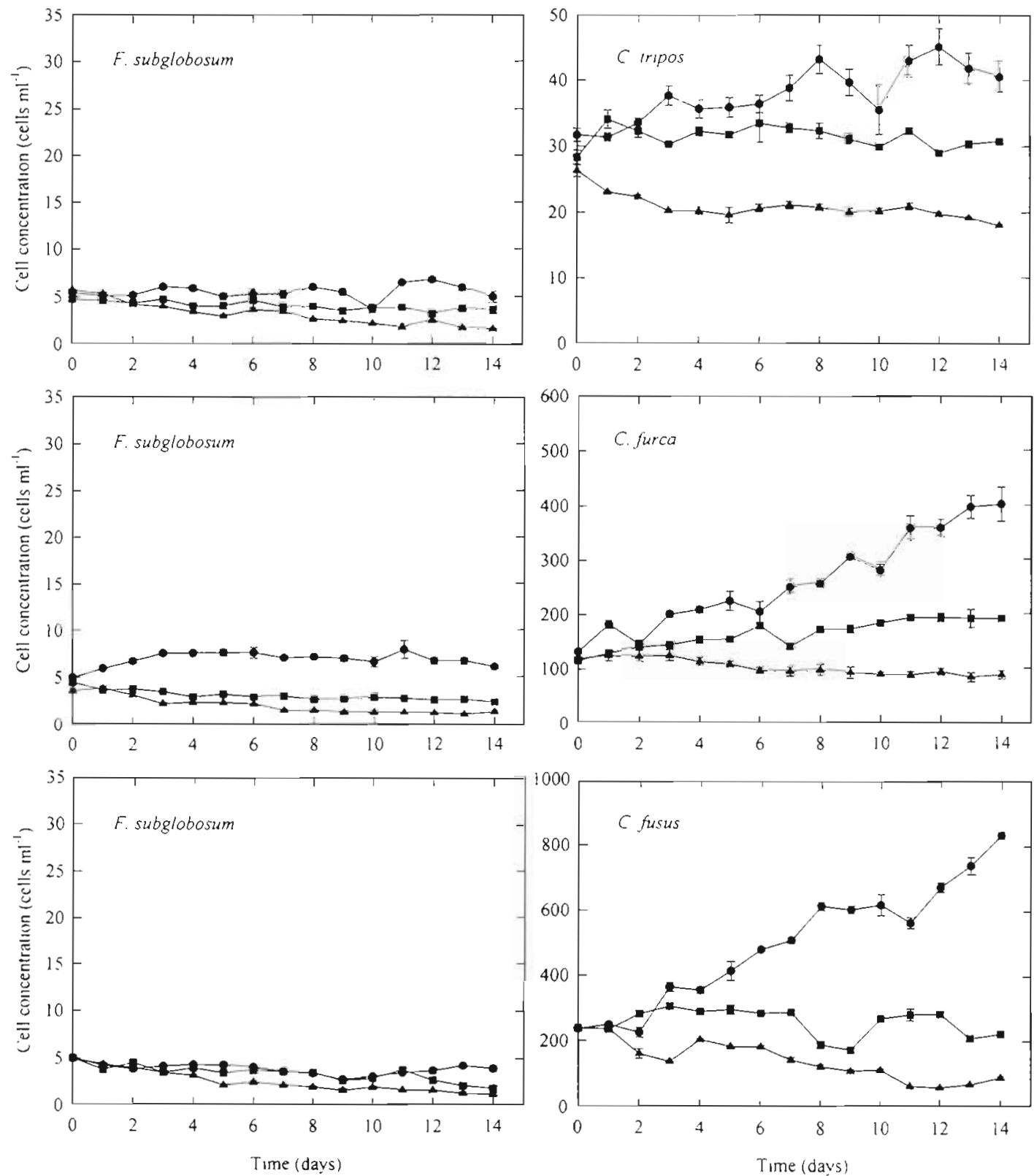

Fig. 5. Growth response of monospecific cultures of Fragilidium subglobosum and 3 Ceratium species: C. tripos, C. furca and C. fusus. Samples were taken daily, resulting in a dilution rate of the batch culture of ca $10 \% \mathrm{~d}^{-1}$ Light intensities (in $\mu$ mol photons $\left.\mathrm{m}^{-2} \mathrm{~s}^{-1}\right):(1) 45 ;(\mathbf{\square}) 22.5 ;(\mathbf{\Lambda}) 9$

\section{Initial prey uptake}

The initial uptake of Ceratium tripos cells by Fragilidium subglobosum, that had previously been grown photoautotrophically, depended on the light intensity to which $F$. subglobosum was exposed (Fig. 9). It made no difference whether $C$. tripos was preincubated at high or low light intensities. The number of F. subglobosum cells containing a food vacuole increased just around the time where light was turned on, indicating an initial diurnal rhythm in the prey uptake of $F$ subglobosum.

\section{DISCUSSION}

\section{Holling type I functional response in Fragilidium subglobosum}

Three types of functional responses have been used to described the relationship between the consumption rate by a predator and changes in prey concentration (Holling 1959). In studies dealing with suspensionfeeding protozoa, data on ingestion rates have often been fitted to a hyperbolic function (e.g. Fenchel 1980, 

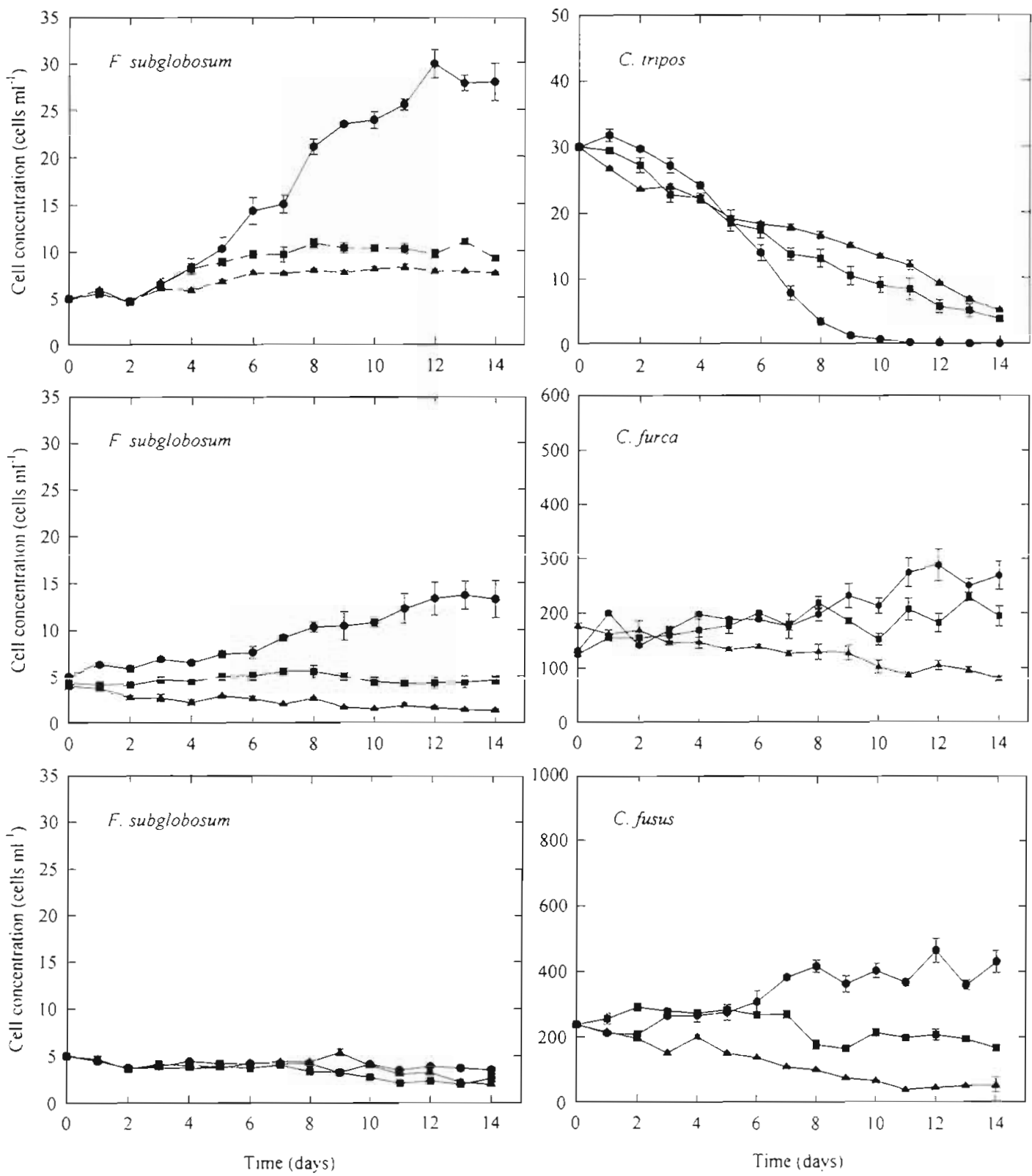

Fig. 6. Growth response of mixed cultures of Fragilidium subglobosum and 3 Ceratium species: C. tripos, C. furca, and C. fusus. Symbols as in Fig. 5

Jonsson 1986). Fenchel (1980) rationalized that this description is functionally analogous to the Holling type II functional response. The model assumes that it takes a finite time for the predator to process a prey. Thus, at low prey concentrations ingestion is limited by predator-prey encounter rate, while at high prey concentrations this 'handling time' will limit ingestion rate. Since $F$. subglobosum only ingests a single $C$. tripos prior to encystment and subsequent cell division, this feeding response is in fact a 'one step' process, based on encounter alone. Thus, the functional response of $F$. subglobosum is a rare example of the Holling type I functional response.

\section{Prey recognition and selection}

Growth and grazing responses of Fragilidium subglobosum are significantly higher when fed the larger species, Ceratium tripos, compared to the 2 smaller species, C. fusus and C. furca (Fig. 7). This observation cannot be explained solely by size selection, because Skovgaard (1996b) found growth rates of F. subglobosum fed C. lineatum (cell volume $8200 \mu^{3}$ ) which are similar to that obtained with $C$. tripos as food, and $C$. lineatum and $C$. tripos are the smallest and largest, respectively, of the 4 species which have been tested. 


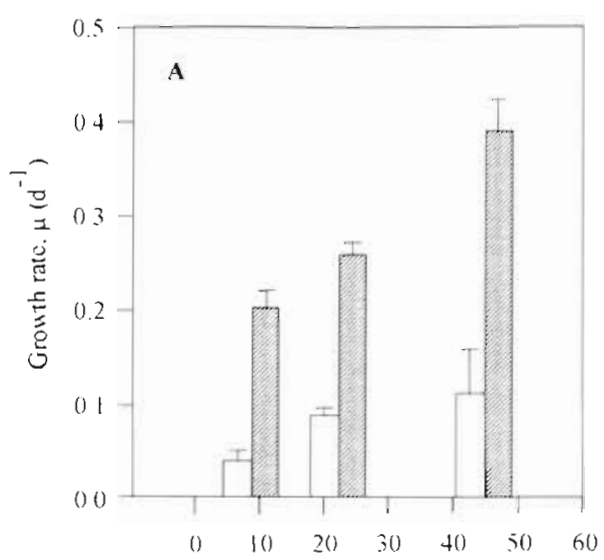

Light intensits $\left(\mu \mathrm{mol} \mathrm{m}^{-2} \mathrm{~s}^{-1}\right)$

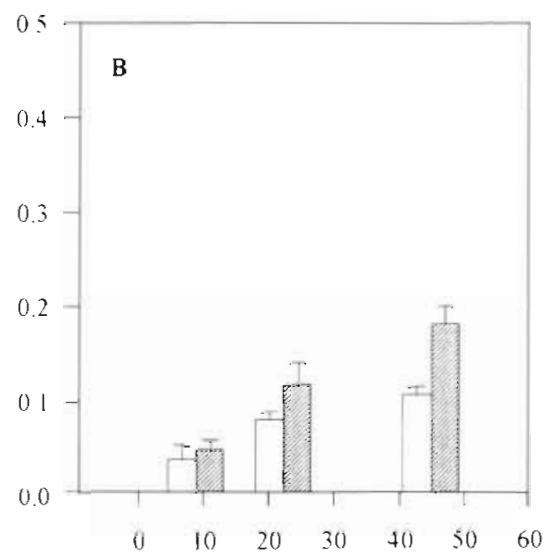

Light intensits $\left(\mu \mathrm{mol} \mathrm{m}^{-2} \mathrm{~s}^{-1}\right)$

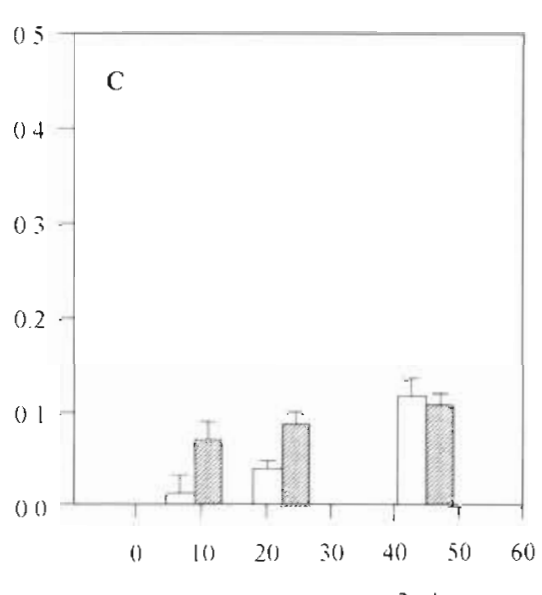

Light intensit! $\left(\mu \mathrm{mol} \mathrm{m}^{-2} \mathrm{~s}^{-1}\right)$

Fig. 7. Growth rates of Fragilidium subglobosum in monospecific culture (open bars) and in cultures supplied with 3 different species of Ceratıum in excess (shaded bars). Bars represent treatment means \pm 1 SD. (A) C. tripos (cell volume $110000 \mu \mathrm{m}^{3}$ ), (B) C. furca $\left(\mathrm{vol}=35000 \mathrm{~m}^{3}\right)$, (C) C. fusus (vol $=12500 \mu \mathrm{m}^{3}$ ). Growth rate as a function of light intensity derived from data shown in Fig. 6. For calculation of growth rate, data from Days 3 to 14 were included, except for C. tripos, where only data from Days 3 to 6 or 8 were included

Since only 1 isolate of each species has been tested, it is uncertain whether this selectivity is species or even clone specific. The fact that dinoflagellates select prey on a basis other than size has been reported for a number of heterotrophic and mixotrophic species. Several species of dinoflagellates belonging to the genera Dinophysis and Ceratium have been shown to feed exclusively on ciliates (Hansen 1992, Bockstahler \& Coats 1993b, Jacobson \& Andersen 1994). In addition to this, some species of the heterotrophic genus Protoperidinium appear to feed on diatoms exclusively, while other species feed on dinoflagellate and/or prasinophyte prey (Jacobson \& Anderson 1986). However, such a high degree of specificity in prey selection is not a general phenomenon in dinoflagellates; some

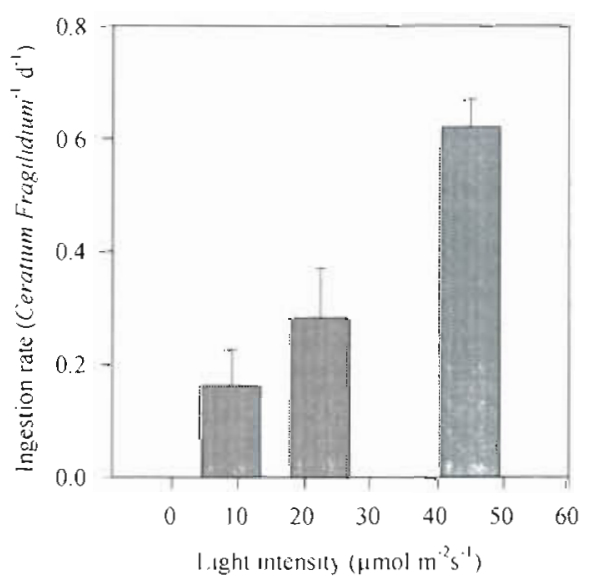

Fig. 8. Fragilidium subglobosum fed Ceratium tripos. Ingestion rates as a function of light intensity derived from data shown in Fig. 7 species are indeed omnivorous (Jacobson \& Anderson 1986, Hansen 1992). Prey selection which cannot be explained by size selection has also been documented in mixotrophic prymnesiophytes (e.g Chrysochromulina; Jones et al. 1993).

The mechanisms of prey selection other than size selection in phytoflagellates is unknown, but several authors have suggested that this may be due to chemosensory behaviour (e.g. Lewandowsky \& Kaneta 1987). Alternatively, the identification of membranebound binding sites on the surface of prey and predator may lead to prey recognition. This mechanism of

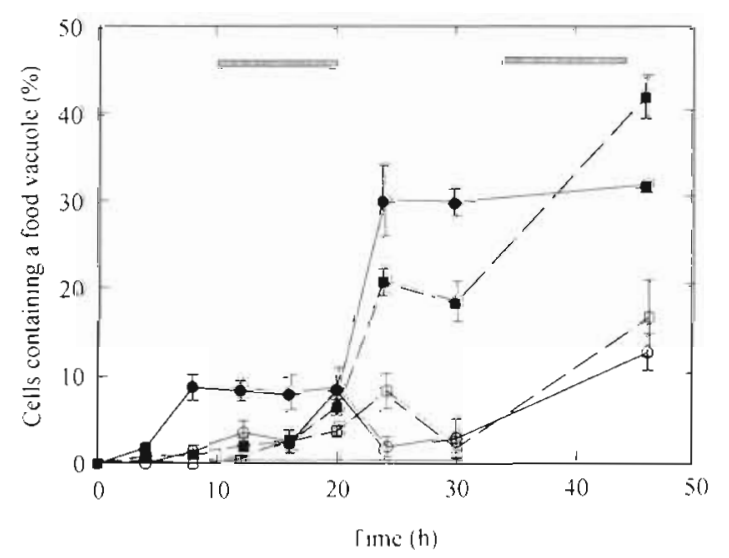

Fig. 9. Initial prey uptake by monospecific cultures of Fragilidium subglobosum fed Ceratium tripos. Percentage of $F$. subglobosum cells containing a food vacuole as a function of incubation time. ( $\square$ and - ) Cultures of $F$. subglobosum exposed to a 'high-light intensity' $\left(9 \mu \mathrm{mol} \mathrm{m}^{2} \mathrm{~s}^{-1}\right)$ and fed $C$. tripos preadapted at a light intensity of 9 and $45 \mu \mathrm{mol}^{-2} \mathrm{~s}^{-1}$. respectively. Shaded areas indicate dark periods (light:dark cycle $14: 10 \mathrm{~h}$ ) 
recognition has been suggested to act in the relationship between symbiotic dinoflagellates and their host (e.g. Trench 1987).

\section{Effects of light intensity and prey concentration on ingestion and growth rates in Fragilidium subglobosum}

The present paper represents the first attempt to study the functional and numerical response of a mixotrophic dinoflagellate in laboratory culture. Cultures of Fragilidium subglobosum grown at $45 \mu \mathrm{mol}$ photons $\mathrm{m}^{-2} \mathrm{~s}^{-1}$ increase their growth rate up to 3 times when fed Ceratium tripos in excess. The maximum specific ingestion rate compares to that of heterotrophic dinoflagellates of a similar size (Hansen et al. in press), indicating that the growth of $F$. subglobosum at this iight intensity primarily depends on phagotrophy, when food is plentiful. This is supported by the fact that the growth yield of $F$. subglobosum grown at $45 \mu \mathrm{mol}$ photons $\mathrm{m}^{-2} \mathrm{~s}^{-1}$ with excess food is not significantiy different fron the growth yielu obtained from $F$. subglobosum grown in the dark and supplied with excess amounts of food (Skovgaard 1996b).

Growth yield increases from about $40 \%$ at prey concentrations which satiate prey ingestion to above $100 \%$ at lower prey concentrations (Fig. 4). Growth yields of this magnitude are of course not realistic, but may be an indication that food uptake by Fragilidium subglobosum stimulates photosynthesis at low prey concentrations. Thus, our data indicate that prey uptake by $F$. subglobosum may provide essential nutrients or growth factors apart from carbon for stimulation of photosynthesis.

Skovgaard (1996b) studied growth and ingestion responses of Fragilidium subglobosum as a function of light intensity in monospecific cultures and in cultures fed Ceratium lineatum in excess. In monospecific cultures of $F$. subglobosum, Skovgaard (1996b) found that growth rate increases as a function of light intensity, reaching a maximum level at ca $130 \mu \mathrm{mol}$ photons $\mathrm{m}^{-2}$ $\mathrm{s}^{-1}$. In mixotrophic cultures, growth rates of $F$. subglobosum did not vary with light intensity within the range of 0 to $365 \mu \mathrm{mol}$ photons $\mathrm{m}^{-2} \mathrm{~s}^{-1}$, even though ingestion rates varied by a factor of 2 to 3 . Maximum ingestion rates were obtained at light levels of between 50 and $120 \mu \mathrm{mol}$ photons $\mathrm{m}^{-2} \mathrm{~s}^{-1}$. At light levels below and above this level, lower ingestion rates were found. In our study, however, both ingestion and growth rates of $F$. subglobosum fed $C$. tripos in excess increased by a factor of 2 to 3 as a function of light intensity between 9 and $45 \mu \mathrm{mol}$ photons $\mathrm{m}^{-2} \mathrm{~s}^{-1}$. This difference in growth response between the 2 studies may relate to differences in prey species. The maxi- mum growth rate of $F$. subglobosum when fed $C$. tripos is similar to that obtained on $C$. lineatum. However, $C$. tripos is 10 times larger (in volume) than $C$. lineatum and this may potentially affect the ingestion rate.

Mixotrophs studied so far have either been primarily phototrophic or phagotrophic. For species that are mainly phototrophs, phagotrophy may be used to acquire major nutrients (nitrogen and phosphorus). Such a strategy for growth might be useful either in well-lit oligotrophic waters or at the pycnocline in stratified waters with nutrient limitation in the upper part (e.g. Bird \& Kalff 1987, 1989, Arenovski et al. 1995 , Havskum \& Riemann 1996). Alternatively, the acquisition of essential growth factors, which the organism is unable to synthesize, is yet an other role for ingestion of prey in primarily phototrophic mixotrophs (Kimura \& Ishida 1986, 1989).

For mixotrophs that are close to the phagotrophic end of the scale, maximum growth rates are only obtained phagotrophically. Consequently, photosynthesis by these mixotrophs has been interpreted as a survival strategy, when prey concentrations are low (Ânủerson el di. 1989, Sanders el di. 1990). Múixotrophy in Fragilidium subglobosum is not an adaptation to either low light or oligotrophic environments. Instead, $F$. subglobosum is a facultative mixotroph, capable of growing purely phototrophically in light without food and purely heterotrophically in the dark, achieving maximum growth rates which are not different from purely heterotrophic or phototrophic dinoflagellates (Skovgaard 1996b). When supplied with high prey concentrations and sufficient light intensity it is able to grow at a rate $\left(\mu=0.5 \mathrm{~d}^{-1}, 15^{\circ} \mathrm{C}\right)$ which is faster than most dinoflagellates of this size.

\section{Ecological significance}

At present it is difficult to evaluate the role of Fragilidum subglobosum as a grazer of Ceratium species in nature, because data on the abundance of F. subglobosum are completely lacking. The lack of reports is probably due the fact that $F$. subglobosum is not easily identified. Identification of $F$. subglobosum is based on a close inspection of the plate pattern. Also, the division cysts of $F$. subglobosum may easily be overlooked in natural samples. However, Ceratium species are prominent members of the late summer phytoplankton community in temperate waters, occasionally forming dense blooms (Nordli 1957, Braarud et al. 1958, Mahoney 1979, Smetacek 1985). In Danish waters, concentrations of $C$. tripos and $C$. lineatum, which are the species preferred by $F$. subglobosum, often exceed 5 and 30 cells $\mathrm{ml}^{-1}$, respectively, during late summer (Jensen 1994). Thus, judged from our experiments, $F$ 
subglobosum has the potential to be an important grazer on the 2 species in nature.

However, a number of factors which have not been dealt with may influence the actual grazing impact by Fragilidium subglobosum. Firstly, the studies conducted so far have only dealt with nutrient-replete cultures. It is a fact that Ceratium species often dominate the phytoplankton community when nutrient limitation may occur. As a consequence of this, Ceratium spp. often form a subsurface maximum at the pycnocline (e.g. Falkowski et al. 1980). Secondly, Ceratium spp. are themselves mixotrophs feeding specifically on ciliates (Bockstahler \& Coats 1993b, Chang \& Carpenter 1994). How this affects their growth rate is unknown. Thus, in order to evaluate the quantitative role of F. subglobosum as grazers on Ceratium spp. populations, field experiments need to be carried out.

Mixotrophy appears to be widespread among phototrophic dinoflagellates. This includes many of the bloom-forming species belonging to genera like Gyrodinium, Gymnodinium, Dinophysis, Prorocentrum, and Ceratium (see Hansen in press for review). We need to know more about the role of mixotrophy in the nutrition of the dinoflagellates. Also we need to study the role of mixotrophy at the community level. Mixotrophic dinoflagellates may gain a competitive advantage over strictly phototrophic forms by removing their competitors for nutrients and at the same time gain a higher growth rate. This raises the question of what role mixotrophy plays in bloom formation and persistence.

Acknowledgements. We are indebted to Conny Moller, Michael Wiberg, Barbera Seider and Birgit Søborg for technical assistance. We thank Tom Fenchel for critically reading the manuscript and for suggesting the ingestion rate calculations. Bent Vismann is acknowledged for setting up the computer model used in the calculation of feeding rates. We also thank David Montagnes for constructive suggestions. The work was funded by the Danish Natural Science Research Council Contract No. 11-0420-1

\section{LITERATURE CITED}

Anderson A, Falk S, Samuelsson G, Hagström G (1989) Nutritional characteristics of a mixotrophic nanoflagellate, Ochromonas sp. Microb Ecol 17:117-128

Arenorski AL, Lim EL, Caron DA (1995) Mixotrophic nanoplankton in oligotrophic waters of the Sargasso Sea may employ phagotrophy to obtain major nutrients. J Plankton Res 17:801-820

Bird DF, Kalff J (1987) Algal phagotrophy: regulating factors and importance relative to photosynthesis in Dinobryon (Chrysophyceae). Limnol Oceanogr 32:277-284

Bird DF, Kalff J (1989) Phagotrophic sustenance of a metalimnetic phytoplankton peak. Limnol Oceanogr 34:155-162

Bockstahler KR, Coats DW (1993a) Grazing of the mixotrophic dinoflagellate Gymnodinium sanguineum on ciliate populations of Chesapeake Bay. Mar Biol 116:477-487
Bockstahler KR, Coats DW (1993b) Spatial and temporal aspects of mixotrophy in Chesapeake Bay dinoflagellates. J Euk Microbiol 40:49-60

Braarud T, Føyn B, Hasle GR (1958) The marine and freshwater phytoplankton of the Dramsfjord and the adjacent part of the Oslofjord March-December 1951 Hvalrådets Skrifter 43:1-102

Caron DA, Sanders RW, Lim EL, Marrasé C, Amaral LA, Whitney S, Aoki RB, Porter KG (1989) Light-dependent phagotrophy in the freshwater mixotrophic chrysophyte Dinobryon cylinaricum. Microb Ecol 25:93-111

Chang J, Carpenter EJ (1994) Inclusion bodies in several species of Ceratium Schank (Dinophyceae) from the Caribbean Sea examined with DNA-specific staining. J Plankton Res 16:197-202

Falkowski PG, Hopkins TS, Walsh JJ (1980) An analysis of factors affecting oxygen depletion in the New York Bight. J Mar Res 38:479-506

Fenchel T (1980) Suspension feeding in ciliated protozoa: functional response and particle size selection. Microb Ecol 6:1-11

Fenchel T (1982) Ecology of heterotrophic microflagellates. II. Bioenergetics and growth. Mar Ecol Prog Ser 8:225-231

Gaines G, Elbrächter M (1987) Heterotrophic nutrition. In: Taylor FJR (ed) The biology of dinoflagellates. Blackwell, Oxford, p 224-268

Hansen PJ (1989) The red tide dinoflagellate Alexandrium tamarense: effects on behaviour and growth of a tintinnid ciliate. Mar Ecol Prog Ser 53:105-116

Hansen PJ (1992) Prey size selection, feeding rates and growth dynamics of heterotrophic dinoflagellates with special emphasis on Gyrodinium spirale. Mar Biol 114:327-334

Hansen PJ (in press) Phagotrophic mechanisms and prey selection in mixotrophic phytoflagellates. In: Anderson DM, Cembella AD, Hallegraeff GM (eds) The physiological ecology of harmful algal blooms. Springer-Verlag, New York

Hansen PJ, Bjornsen PK, Hansen B (in press) Zooplankton grazing and growth: scaling within the $2 \mu \mathrm{m}-2000 \mu \mathrm{m}$ body size. Limnol Oceanogr

Havskum H, Riemann B (1996) Ecological importance of bacterivorous, pigmented flagellates (mixotrophs) in the Bay of Aarhus, Denmark. Mar Ecol Prog Ser 137:251-263

Holling CS (1959) Some characteristics of simple types of predation and parasitism. Can Entomol 91:385-398

Jacobson DM, Andersen RA (1994) The discovery of mixotrophy in photosynthetic species of Dinophysis (Dinophyceae): light and electron microscopical observations of food vacuoles in Dinophysis acuminata, D. norvegica and two heterotrophic dinophysoid dinoflagellates. Phycologia 33:97-110

Jacobson DM. Anderson DM. (1986) Thecate heterotrophic dinoflagellates: feeding behavior and mechanism. J Phycol 22:249-258

Jacobson DM, Anderson DM (1996) Widespread phagocytosis of ciliates and other protists by marine mixotrophic and heterotrophic thecate dinoflagellates. J Phycol 32:279-285

Jensen BS (1994) Fire udvalgte Ceratium-arters biologi, okologi og udbredelse i danske farvande. Masters thesis, University of Aarhus

Jones HLJ, Leadbeater BSC, Green JC (1993) Mixotrophy in marine species of Chrysochromulina (Prymnesiophyceae): ingestion and digestion of a small green flagellate. J Mar Biol Ass UK 73:283-296

Jonsson PR (1986) Particle size selection, feeding rates and growth dynamics of marine planktonic oligotrichous ciliates (Ciliophora: Oligotrichina). Mar Ecol Prog Ser 33: $265-277$ 
Keller MD (1994) Phagotrophy of fluorescently labelled bacteria by an oceanic phytoplankter Microb Ecol 28:39-52

Kimura B, Ishida Y (1986) Possible phagotrophic feeding on bacteria in a freshwater red tide chrysophyceae Uroglena americana. Bull Jpn Soc Sci Fish 52:697-701

Kimura B, Ishida Y (1989) Phospholipid as a growth factor of Uroglena americana, a red tide chrysophyceae in Lake Biwa. Nippon Suisan Gakk 55:799-804

Lessard EJ, Swift E (1985) Species-specific grazing rates of heterotrophic dinoflagellates in oceanic waters, measured with a dual-label radioisotope technique. Mar Biol 87:289-296

Lewandowsky M, Kaneta P (1987) Behaviour in dinoflagellates. In: Taylor FJR (ed) The biology of dinoflagellates. Blackwell, Oxford, p 360-398

Li A, Stoecker DK, Coats DW, Adam EJ (1996) Ingestion of fluorescently labelled and phycoerythrin-containing prey by mixotrophic dinoflagellates. Aquat Microb Ecol 10:139-147

Mahoney JB (1979) Environmental and physiological factors in growth and seasonal maxima of the dinoflagellate Ceratium tripos. Bull New Jersey Acad Sci 24:28-38

Neuer S, Cowles TJ (1995) Comparative size-specific grazing rates in field populations of ciliates and dinoflagellates. Mar Ecol Prog Ser 125:259-26?

Nordli E (1957) Experimental studies on the ecology of Ceratia. Oikos 8:1-265

Nygaard K, Tobisen A (1993) Bacterivory in algae: a survival strategy during nutrient limitation. Limnol Oceanogr 38 : $273-279$

This article was submitted to the editor
Sanders RW, Porter KG, Caron DA (1990) Relationships between phototrophy and phagotrophy in the mixotrophic chrysophyte Poteriochromonas malhamensis. Microb Ecol 19:97-109

Schnepf E, Elbrächter $M$ (1992) Nutritional strategies in dinoflagellates: a review with emphasis on cell biological aspects. Eur J Protistol 28:3-24

Skovgaard A (1996a) Engulfment of Ceratium spp. (Dinophyceae) by the thecate photosynthetic dinoflagellate Fragilidium subglobosum. Phycologia 35:400-409

Skovgaard A (1996b) Mixotrophy in Fragilidium subglobosum (Dinophyceae): growth and grazing responses as functions of light intensity. Mar Ecol Prog Ser 143: $247-253$

Smetacek V (1985) The annual cycle of Kiel Bight plankton: a long-term analysis. Estuaries 8:145-157

Stosch HA von (1969) Dinoflagellaten aus der Nordsee II. Helgolandinium subglobosum gen. et spec. nov. Helgoländer Wiss Meeresunters 19:569-577

Thomsen HA (1992) Plankton i de indre danske farvande Havforskning fra Miljestyrelsen, nr. 11. Danish National Agency of Environmental Protection, Copenhagen

Trench RK (1987) Dinoflagellates in non-parasitic symbioses. In: Taylor FJR (ed) The biology of dinoflagellates. Blackwell, Oxford, p 530-570

Veen A (1991) Ecophysiological studies on the phagotrophic phytoflagellate Dinobryon divergens Imhof. PhD thesis, Unıversität van Amsterdam

Manuscript first received: May 10, 1996

Revised version accepted: December 23, 1996 